\title{
ROLE OF RAILWAY TRANSPORT IN TOURISM: SELECTED PROBLEMS AND EXAMPLES IN SLOVAKIA
}

\author{
DANIEL MichNiAK \\ Institute of Geography, Slovak Academy of Sciences, Bratislava, Slovakia
}

Manuscript received: December 21, 2015

Revised version: October 4, 2016

\begin{abstract}
MichNiAK D., Role of railway transport in tourism: Selected problems and examples in Slovakia. Quaestiones Geographicae 35(4), Bogucki Wydawnictwo Naukowe, Poznań, pp. 107-120, 12 figs, 2 tables.

ABSTRACT: Transport is a very important part of activities in the tourism sector. In addition to the transport of tourists to and within a destination, transport itself can be a tourist attraction. The aim of this paper is to analyse selected problems of railways in Slovakia (a decrease in the importance of railways for passenger transport in Slovakia in the past 20 years, discontinued passenger transport on certain railway tracks and the modernisation of other tracks, and zero-fare public rail transport services for certain categories of passengers), and to present good examples of the use of narrow-gauge railways for the purposes of tourism (the Tatra Electric Railways and the Kysuce-Orava Forest Railway).
\end{abstract}

KEY WORDS: railway transport, zero-fare public rail transport services, narrow-gauge railways, tourism, Slovakia

Daniel Michniak, Institute of Geography, Slovak Academy of Sciences, Štefánikova 49, 81473 Bratislava, Slovakia; e-mail: geogmich@savba.sk

\section{Introduction}

There is a close relationship between transport and tourism. Different transport modes have played different roles in the development of tourism that has changed over time. The aims of this paper are (1) to analyse selected problems of railways in Slovakia, and (2) to provide good examples of the use of narrow-gauge railways for the purposes of tourism. At the beginning, the relationship between transport and tourism is outlined and Slovakia as a tourist destination is shortly presented. In the first part, the position of railways and railway transport in Slovakia is assessed (the position of railways in Slovakia, railway infrastructure, the organisation of railway transport, zero-fare public rail transport, and the closure of passenger transport on several regional tracks). In the second part, narrow-gauge railways in Slovakia and their use for tourist purposes are introduced. Attention is paid to selected good examples of the use of railways for the development of tourism (e.g. the Tatra Electric Railways and the use of former forest railways for tourism - the Kysuce-Orava Forest Railway).

\section{Relationship between transport and tourism}

Transport is an integral part of activities in the tourism sector. Transport, together with the tourist product (or supply) and the tourist market (or demand), is one of the three fundamental components of tourism. Tourism could not develop to such an extent without the development of 
transport, and most forms of tourism could not exist without transport (Page 2009). According to Lohmann and Duval (2011), there is a strong co-dependence between the sectors of transport and tourism, because transport relies on the viability and attractiveness of a destination, and a destination relies on transport for visitor access. Different roles of transport have been identified in terms of the movement of tourists. Transport ensures a link between the source market (region) and the host destination (region); it provides mobility and access within a destination region or a tourist attraction, and it can itself be a tourist experience (Hall 1999: 181).

The evolution of transport has brought about reduced travel times, travel cost and number of passengers carried. According to Tolley and Turton (1995), four phases of transport technology can be identified: the transition from horse and wind power, the introduction of the steam engine, the development of the combustion engine, and the use of the jet engine. Stradling and Anable (2008) distinguish three methods of human transport: self-propelled modes (e.g. walking), augmented modes (using technology or tools to amplify our bodily effort, such as cycling and skiing), and fuelled modes (especially motorised transport).

Over the recent centuries, different transport modes have been crucial accelerators of the development of tourism. The building of railways in the $19^{\text {th }}$ century led to a growing number of people travelling as tourists, railways becoming the first mass form of transport (Page 2014). Rail travel was the dominant form of mass public transport before the age of the automobile (Rodrigue et al. 2006). In the $20^{\text {th }}$ century, automobile transport took the dominant role in the transport of tourists. In the second half of the $20^{\text {th }}$ century, air transport became a global phenomenon responsible for the growth of tourism (Duval 2007). The main transport modes used in the tourism sector at present are car travel, coach travel, rail travel, air transport, and cruises (Rodrigue et al. 2006). The main advantages of car travel are flexibility and independence. Coaches (buses) are suitable for mass tourism for short-term local tours (hours), but also for long-term multi-day journeys as learning or adventure travel tours. The main drawback of rail travel is its rather inflexible infrastructure. Several countries, mainly in Europe, East Asia and North America, have invested in building high-speed railway systems that have brought rail travel a better position in the modal split. Air travel is important mainly for international tourism. The expansion of lowcost airlines has had a significant, positive effect for the tourism market (Rey et al. 2011; Chung, Whang 2011). Cruises include mainly various sea journeys where guests can enjoy luxury and entertainment while moving towards their multiple destinations. Cruising has become a significant tourist industry and is concentrated mainly in the Caribbean and the Mediterranean (Rodrigue et al. 2006). Each transport mode mentioned above has an indispensable role in the development of tourism. The importance of individual transport modes depends on the organisation of the transport system at local, regional, national or international levels.

There are many studies that deal with the relationship between railway transport and tourism. Many scholars have studied the railway heritage and its importance for tourism (e.g. Halsall 2001; Hörz, Richter 2011; Conlin, Bird 2014). According to Boughey (2013), when some railway routes have become obsolete for transport, there is an opportunity to use them for the development of tourism in the form of leisure-oriented transport, or the conservation of engineering structures or sites retained for nature, general amenity, historic environments, or contributions to the landscape. Other authors (e.g. Masson, Petiot 2009; Delaplace et al. 2014) have focused on the influence of highspeed rail on tourist attractiveness and the choice of a tourist destination. The construction of highspeed rail leads to an improvement in destination accessibility, but also means a reinforcement of spatial competition between tourist destinations (Masson, Petiot 2009). Prideaux (1999) points to the importance of long-distance passenger rail services as an alternative for travellers who prefer automobile and air transport for long-distance tourism. Dallen (2007) considers the diversity of passenger behaviour and attitudes among tourists and leisure visitors, and sets the research findings in the context of future railway policy for sustainable transport access at tourist destinations. Kumar and Komaraiah (2014) stress the role of railways in the promotion of tourism.

Blancheton and Marchi (2013) distinguish three systems in railway tourism, which they 
regard as a macro-system. In the first, the operator has a rolling stock and its own railway line at its disposal (tourist railway, narrow-gauge railway, a line with tourist potential). In the second, the operator has the rolling stock at its disposal, but the trains come in between existing traffic operated by another organisation (a vintage train, a luxury or prestige train). In the third system, the operator acts as an intermediary that charters the whole or a part of a tourist train belonging to the first or second systems.

\section{Tourism in Slovakia}

The post-1989 transition in Central and Eastern Europe has had a major impact on the development of tourism in the region. Johnson (1995) reviews some of the developments in the tourist industry which have taken place in the Czech Republic and Slovakia since 1989, and concludes that various policies are needed to improve infrastructure, promote the integration of tourist services, maintain visitor numbers, and encourage guests to stay longer, visit additional locations, and increase their spending. Williams and Baláž (2002) discuss conceptual issues in the economic analysis of tourism in transition with the focus on the Czech Republic and Slovakia: path dependency, property rights and privatisation, the nature of markets and regulation, re-internationalisation and globalisation, and the polarisation of consumption. Copp and Ivy (2001) identify a growing trend towards the adoption of formal networking patterns in Slovakia similar to those in more developed market economies. Tourist clusters in Slovakia as a tool for the improvement of regional competitiveness is the main topic of other studies, e.g. Székely $(2010,2014)$ and Čuka et al. (2012). Vystoupil et al. (2016) propose a new functional typology of tourist resorts in Slovakia.

There are favourable preconditions for the development of various kinds of tourism in Slovakia. It is a small country in Central Europe with 5.4 million inhabitants. The centre and north of the country are mountainous (the Carpathians), and in the south and south-east there are lowlands. The most important river, Danube, links Bratislava, the capital of Slovakia, with Vienna and Budapest. Vienna and Bratislava are the closest capital cities in Europe (only $65 \mathrm{~km}$ apart). Tourists are attracted by many natural beauties, especially mountains and caves, as well as cultural and historical attractions such as medieval castles and towns, folk architecture, spas and ski resorts. Many natural beauties are concentrated in nine national parks and other protected areas. The caves of the Slovak Karst and primeval beech forests of the Carpathians are parts of the UNESCO World Natural Heritage. The World Cultural Heritage is represented by the historic town of Banská Štiavnica and the technical monuments in its vicinity, as well as the town of Levoča, the Castle of Spišský hrad and the associated cultural

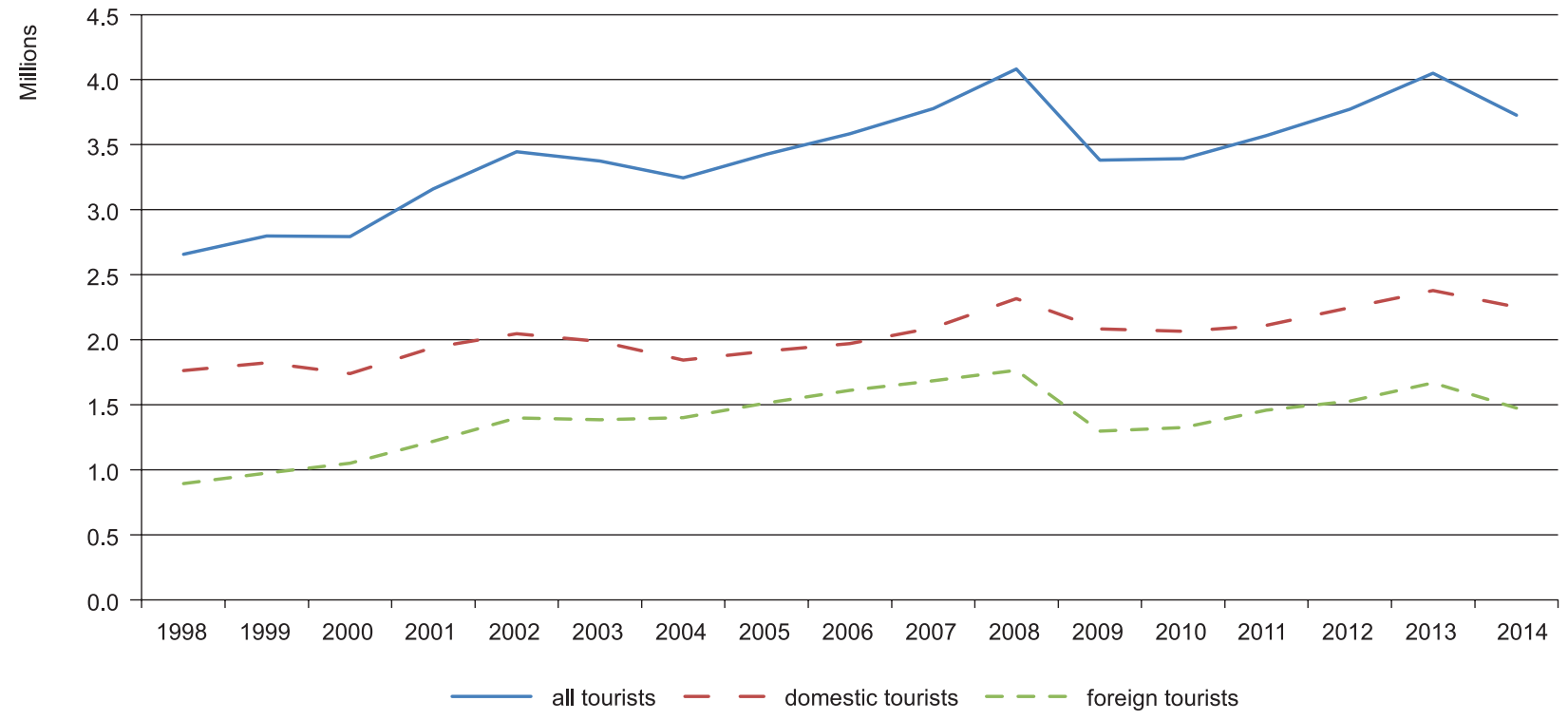

Fig. 1. Number of tourists in Slovakia, 1997-2014.

Source: own elaboration based on data from the Statistical Office of the SR (ŠÚSR 2015). 


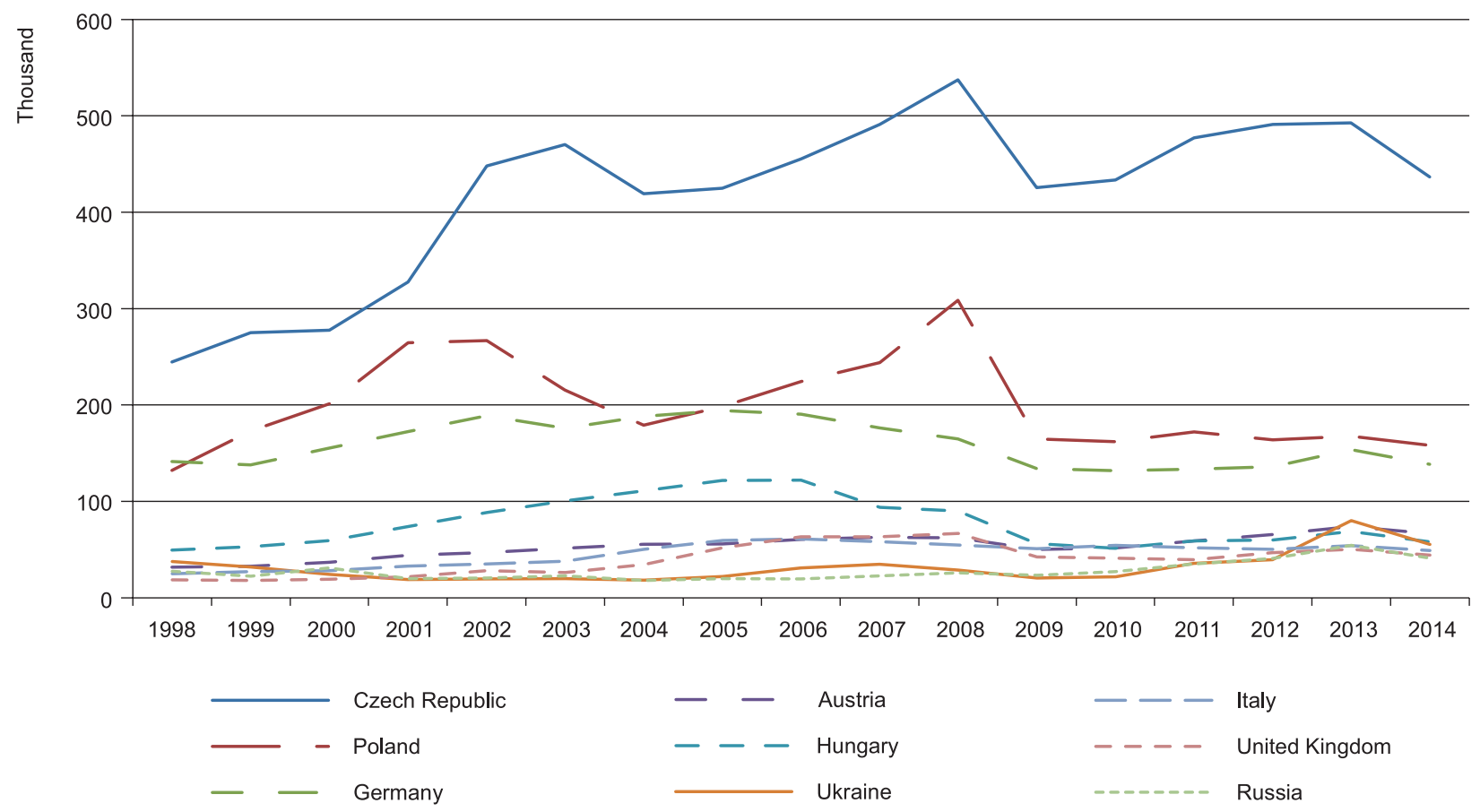

Fig. 2. Structure of foreign tourists in Slovakia, 1997-2014.

Source: own elaboration based on data from the Statistical Office of the SR (ŠÚSR 2015).

monuments, the Bardejov town conservation reserve, the village of Vlkolínec, and eight wooden churches of the Slovak part of the Carpathian mountain area.

The average number of tourists visiting Slovakia (see Fig. 1) is approximately 3.5 million a year (1.5 million of foreign tourists in 2014). Domestic tourists prevail over foreign ones (60\%:40\%). Tourists from the neighbouring countries (especially the Czech Republic and Poland) and other largest European states (e.g. Germany, Italy, the UK, Russia) visit Slovakia most often (Fig. 2). The most visited tourist regions in Slovakia include the city of Bratislava, the High Tatras, and the Liptov region.

\section{Railway infrastructure in Slovakia}

Railway infrastructure is only a prerequisite for the development of railway transport and for good spatial accessibility of tourist destinations. The present Slovak railway network is the result of more than 150-year development in various natural, economic and political conditions. The country's natural conditions have greatly influenced the course of lines, and so have the changing economic and political conditions during the political systems that existed on the territory of present-day Slovakia (Austria-Hungary, the First Czechoslovak Republic, the Slovak State during the Second World War, the period of socialism, disintegration of Czechoslovakia, the accession of Slovakia to the EU). Today, EU membership is the decisive factor, which manifests itself in the modernisation of tracks included into the TEN-T corridors (Michniak 2006). Slovakia has three Core Network Corridors crossing the country: the Baltic-Adriatic corridor, the Orient/EastMed corridor, and the Rhine-Danube corridor. The total length of the railway lines operated in Slovakia in 2014 was 3,581 km (Fig. 3).

A low technological level and quality as well as neglected maintenance characterised Slovak railway transport at the end of the $20^{\text {th }}$ century. There have been efforts to improve railway transport via the modernisation of railway infrastructure (increasing the speed limit to $160 \mathrm{~km} / \mathrm{h}$ ). This modernisation concentrates mainly in the western part of the country on the main Slovak track from Bratislava to Žilina. By 2014, a continuous 114-km-long Bratislava-Rača-Zlatovce track had been adapted for a speed of $160 \mathrm{~km} / \mathrm{h}$. In addition, a 19-km section of the main railway track, between Žilina and Krásno nad Kysucou, had also been upgraded. As of 30 June 2013, a total of one billion euros had been invested in construction works for railways. More than a half of those 


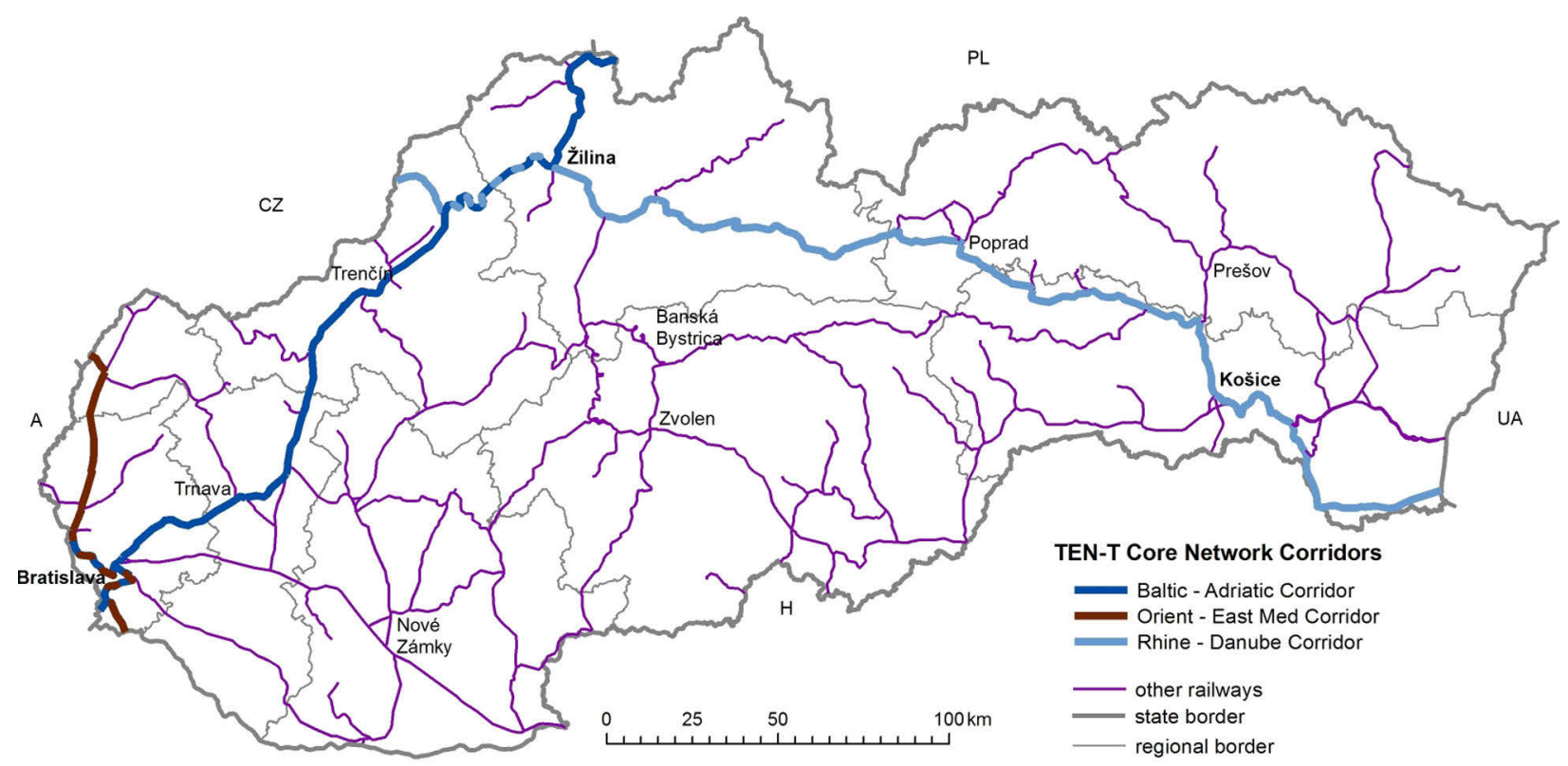

Fig. 3. TEN-T Core Network Corridors in the railway network of Slovakia. Source: own elaboration.

Table 1. Modernisation of railways in Slovakia for the speed of $160 \mathrm{~km} / \mathrm{h}$.

\begin{tabular}{|l|c|c|}
\hline \multicolumn{1}{|c|}{ Railway track } & Period & Length \\
\hline $\begin{array}{l}\text { Bratislava - Rača - Nové Mesto } \\
\text { nad Váhom }\end{array}$ & $2002-2009$ & $92 \mathrm{~km}$ \\
\hline Žilina - Krásno nad Kysucou & $2008-2011$ & $19 \mathrm{~km}$ \\
\hline $\begin{array}{l}\text { Nové Mesto nad Váhom - } \\
\text { Zlatovce }\end{array}$ & $2009-2013$ & $22 \mathrm{~km}$ \\
\hline $\begin{array}{l}\text { Trenčianska Teplá - Ilava - } \\
\text { Beluša - Púchov }\end{array}$ & $2009-2014$ & $27 \mathrm{~km}$ \\
\hline Zlatovce - Trenčianska Teplá & $2012-2016$ & $12 \mathrm{~km}$ \\
\hline
\end{tabular}

Source: Own elaboration based on data from websites of individual narrow-gauge railways.

funds (572 million) came from the EU pre-accession ISPA and Cohesion Funds.

The construction of new high-speed railway lines (with a speed limit of more than $200 \mathrm{~km} / \mathrm{h}$ ), like those built in several EU countries, is not contemplated in Slovakia. There are some visions, but at present there are no funds and there are other priorities, e.g. the construction of motorways. A study of high-speed railway which should link the three cities of Vienna, Bratislava and Budapest within the TEN-T Rhine - Danube corridor could receive funds from Connecting Europe Facility - the tool created to support EU infrastructures.

\section{The position of railways in passenger transport in Slovakia}

In Europe, rail travel has experienced a relative loss of the market share to road travel after the 1970s because of the development of bus and individual automobile transport. A decrease in the importance of public transport in Slovak passenger transport has also been obvious over the past 20 years (Fig. 4). In 1995, the load of public transport was bigger than that of individual thousand million pkm

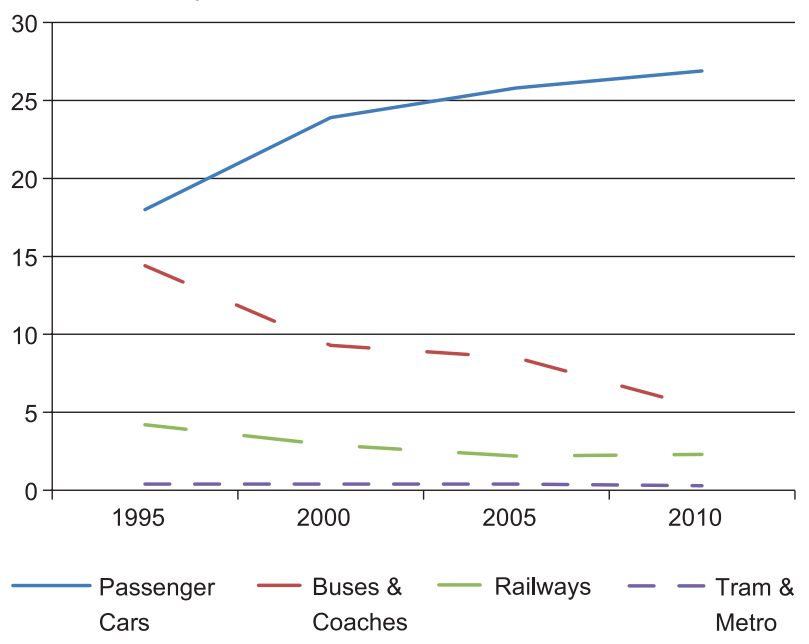

Fig. 4. Performance of passenger transport expressed in passenger-kilometres in Slovakia.

Source: EU transport in figures, Statistical Pocketbook 2012. 


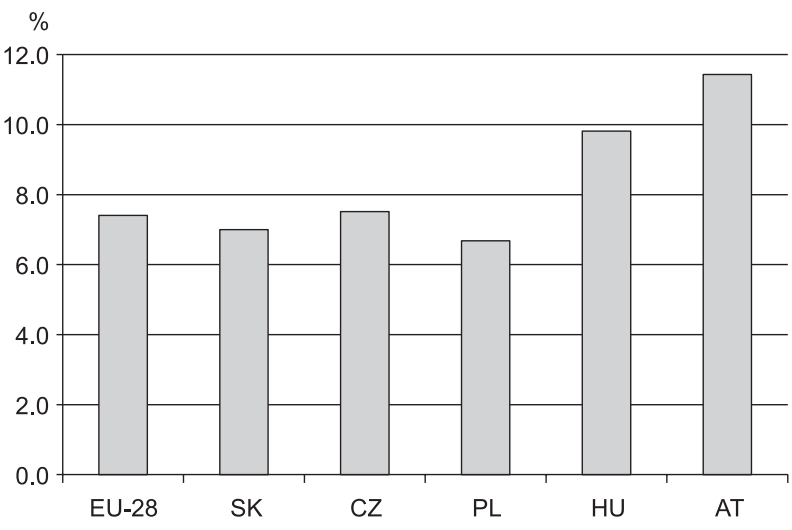

Fig. 5. Share of railways in the modal split of passenger transport on land in selected countries in 2012 (pkm in \%).

Source: EU transport in figures, Statistical Pocketbook 2012.

automobile transport. Railways as well as buses and coaches have lost their relative position and passenger cars have become the most important transport means of travelling in Slovakia.

The share of railways in the modal split of passenger transport on land in 2012 was lower than the EU average (Fig. 5). In comparison with the neighbouring EU countries, railways have a weaker position only in Poland.

The negative phenomenon that influences railway transport in Slovakia is the closure of passenger transport on several regional tracks (Fig. 6). In total, passenger services were withdrawn on more than $530 \mathrm{~km}$ of railway tracks between 2000 and 2012. The southern part of the country was most affected by those measures (Michniak 2015).

Regional railway closures bring immediate effect in the form of lower operating costs. But other consequences for passenger traffic can be dramatic for many inhabitants who are socially deprived and excluded, and they are not taken into account. The closure of regional railway passenger transport services affects commuting in the given region, the mobility of visitors, and may negatively influence the region's further development. This negative impact can be seen in the southern part of Central Slovakia, which suffers from an unfavourable economic situation, a low quality of human potential, a high unemployment rate, poverty, and also a reduction in regional railway transport.

On the other hand, the quality of passenger transport on the remaining regional tracks in Slovakia is gradually improving as new regional train units have been purchased with the help of EU funds under the Transport Operational Programme.

\section{Organisation of railway transport in Slovakia}

The organisation of railway transport is important for efficient functioning. The railways of

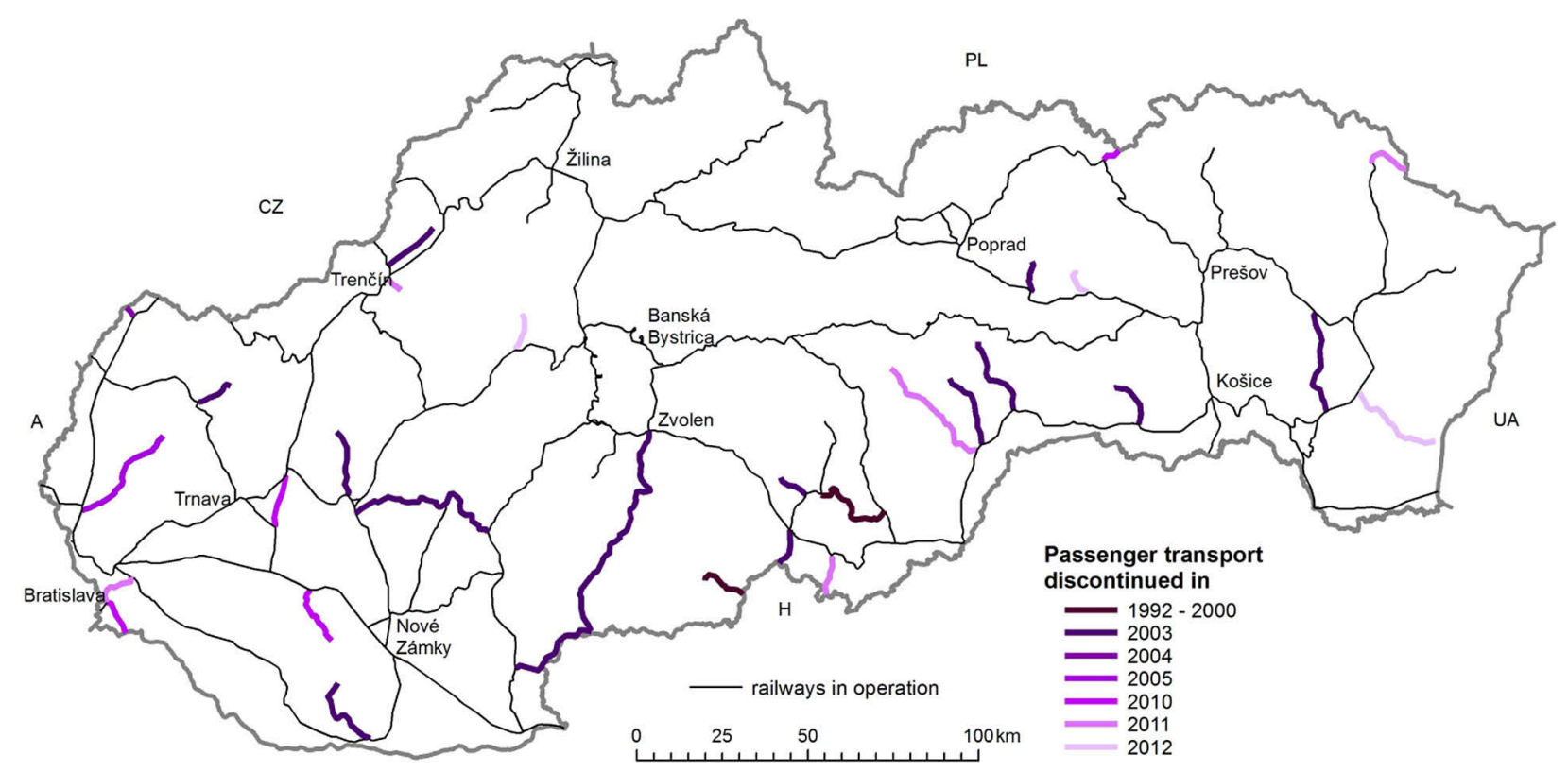

Fig. 6. Railway closures after 1990 in Slovakia.

Source: own elaboration based on data from http:/ / www.slovakrail.sk/ 
the Slovak Republic (Železnice Slovenskej republiky - ZSR) were set up on 1 January 1993 by the decision of the Slovak Government on the establishment of a state enterprise following the split of Czechoslovakia and thus the division of the Czechoslovak State Railways into two independent entities.

Under the Project of the Transformation and Restructuring of the Company, as of 1 January 2002 the railways were split into two separate entities: the Railways of the Slovak Republic (ZSR) and the Railway Company. On 1 January 2005, the Railway Company was divided into the Slovakia Railway Company (Železničná spoločnost' Slovensko, a.s. - ZSSK) and Cargo Slovakia, ensuring passenger and freight transport, respectively.

The ZSR ensures the management and operation of railway infrastructure in Slovakia. The ZSSK is a state railway carrier, established and owned $(100 \%)$ by the Slovak Republic, represented by the Ministry of Transport, Construction and Regional Development of the Slovak Republic. Public railway transport is provided by the state via the Contract on Performance in the Public Interest upon Operation of Transport on the Railway concluded between the Ministry of Transport of the Slovak Republic and the ZSSK, which quantifies tasks and the compensation of loss due to their implementation.
The Slovak Republic opened its monopolistically dominated railway market to private operators only in 2011 (see Fig. 7). RegioJet has been the first private carrier in passenger railway transport in Slovakia since the end of 2011. Its service started with one pair of trains in the IC category on a daily basis on the Žilina - Ostrava - Praha route. In March 2012, it started operating on the Bratislava - Dunajská Streda - Komárno railway track, and in December 2014, on the main railway track in Slovakia: Bratislava - Žilina - Košice. Direct competition between the private and the public passenger carrier started in December 2014. The second private carrier in passenger railway transport is LEO Express that provides one pair of trains daily on the Praha - Ostrava Žilina - Košice route since December 2014.

For comparison, in the Czech Republic open-access competition in the passenger railway sector started already in 2003 on the PragueOstrava route where the three major operators include the national operator, České dráhy (CD), and two private players, RegioJet and LEO Express (Jade et al. 2015).

It is difficult to assess the potential consequences of deregulation in the rail sector in Slovakia at present. Competition in the passenger railway sector has only just started and leads to falling prices on several routes. It can contribute

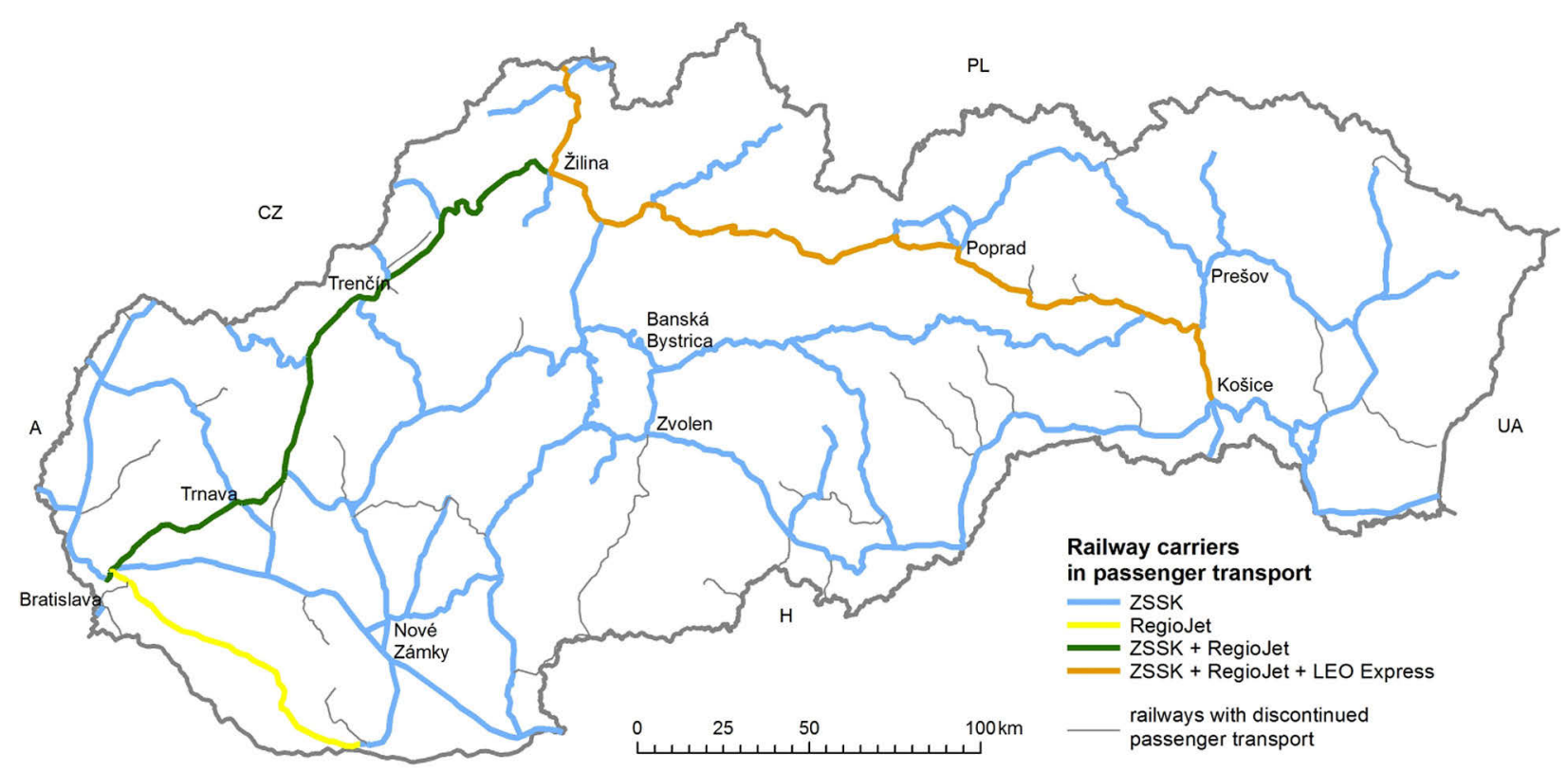

Fig. 7. Railway carriers in passenger transport in Slovakia in 2015. Source: own elaboration based on data from http:/ / www.slovakrail.sk/ 
to an increase in the number of travellers for the purposes of tourism.

Services provided to passengers in railway transport can be divided into four categories. Railways ensure regular and irregular passenger transport, and services are offered on the train or at railway stations. Regular railway transport includes international, national long-distance, regional and suburban services. Irregular passenger rail transport includes, e.g., special trains, historic trains, special cars or trains to order. Services on the train (on-board services) comprise the carriage of luggage (baby carriages, bicycles, skis or other objects); transport of animals; refreshments on the train (a dining car or food delivery service personnel with an itinerant mini-bar), couchettes and sleeping cars; wagons for carriage vehicles. Services provided at railway stations include, e.g., a cash desk, information offices, waiting rooms, luggage storage, refreshments, bike rental, and car rental.

With the aim of attracting customers, railway carriers offer discounts for different categories of travellers or special marketing products in cooperation with other companies in the tourism sector (service packages combining railway transport with a visit at events and other tourist attractions). All those services and their price and quality decide about the selection of rail as the transport means for tourism.

Another measure that could help the development of tourism is zero-fare public rail transport services in Slovakia for children, students and seniors. It is important mainly for the development of short-term tourism on longer distances because transport costs will be lower.

Zero-fare public rail transport services are valid on the trains of the Železničná spoločnost' Slovensko, a.s. carrier and on the Bratislava Komárno line of the RegioJet carrier since 17 November 2014 (the Day of Struggle for Freedom and Democracy - a public holiday in Slovakia). This form of state support benefits children under 15 years of age and seniors over 62 without limitation as to the EU citizenship or residence, as well as students and seniors under 62 who are citizens or permanent residents of the EU member states. There are some limitations of this measure (registration, a ticket bound to a specific train, second class, the zero-fare not valid in the IC category of trains). Passengers entitled to zero-fare transport services are required to register at ZSSK cash desks. Upon registration, they will obtain rail customer cards that will allow them to get zero-fare tickets for travelling by trains. Zero-fare tickets are passenger-specific and train-specific (for long-distance trains only), i.e. the tickets are non-transferable and bound to a specific train. Zero-fare tickets are bound to long-distance trains of the R, Ex, EN, EC, and SC categories.

The zero-fare policy has been a response of the ZSSK to direct competition with RegioJet since December 2014. It is a political rather than an expert decision, and will cost at least 13 million euros a year. 24 million passengers have used free transport a year so far, accounting for $43 \%$ of all train passengers (Morháčová 2015). Not all regions and their inhabitants can benefit from this service because it is not accessible in all regions of Slovakia (see e.g. Michniak 2006).

\section{Narrow-gauge railways and their use for tourist purposes}

Narrow-gauge railways had an important position in the economic development of many regions in Slovakia mainly in the first part of the $20^{\text {th }}$ century (see e.g. Kubáček 1999, Bílek 2000). Forest narrow-gauge railways represent one of the most important chapters in the history of Slovak railway transport. Their total length at the time of their peak development in the first half of the $20^{\text {th }}$ century reached nearly $1,200 \mathrm{~km}$ in 40 localities. They were used for the transport of timber from mountain valleys to the main railway lines or to factories of the timber-processing industry. The largest systems of forest railways, more than $100 \mathrm{~km}$ long, existed near Hronec (today the Čiernohronská Forest Railway), in the Orava and Kysuce region (the Kysuce-Orava Forest Railway), and near Liptovský Hrádok (the Považská Forest Railway).

Field (agricultural) narrow-gauge railways were built at the beginning of the 20th century in lowland agricultural areas of southern Slovakia. They served to transport agricultural crops (mainly sugar beets) from places of production to a processing plant (refinery). In southern Slovakia four extensive field rail systems 


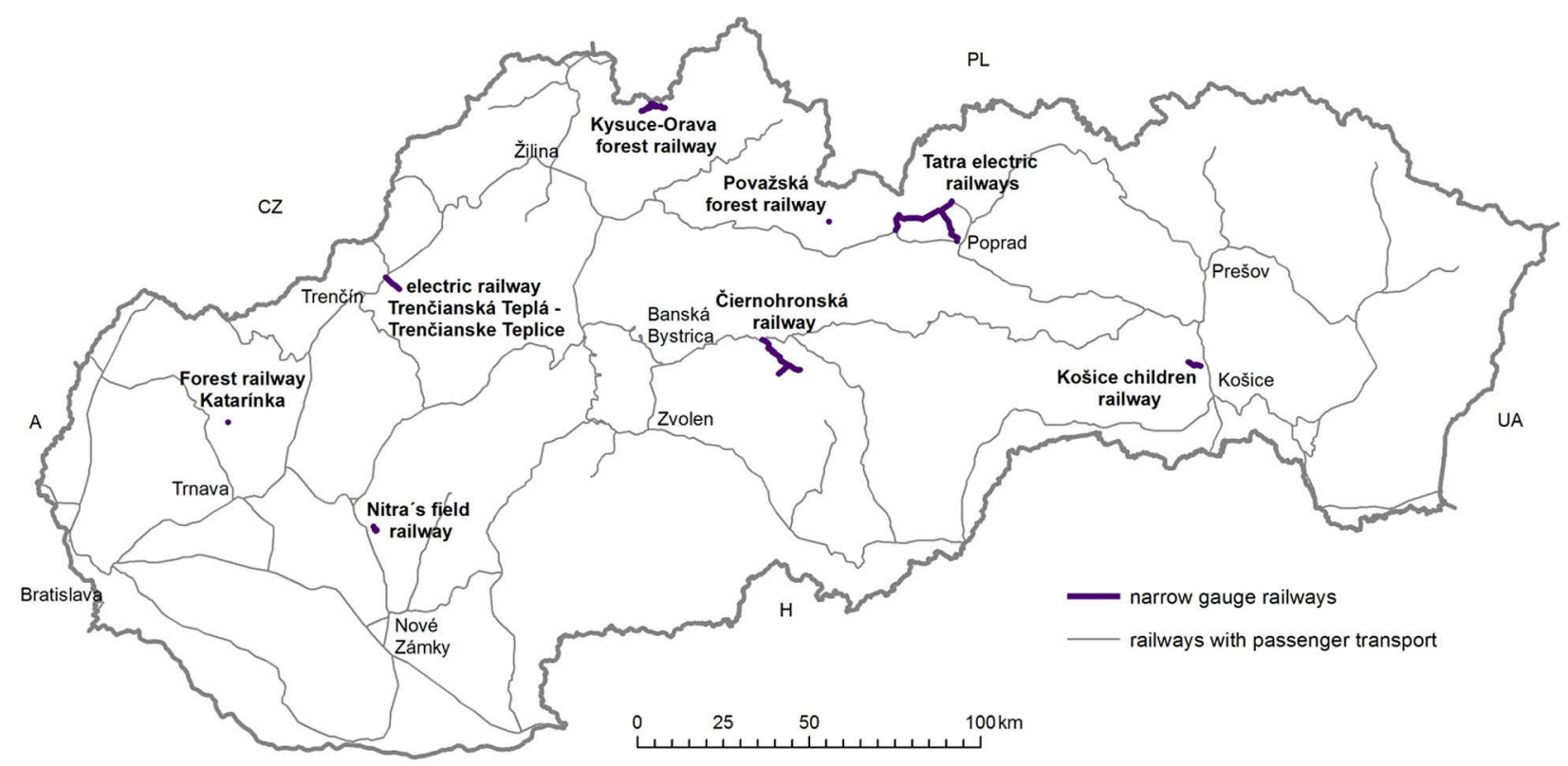

Fig. 8. Narrow-gauge railways in Slovakia. Source: own elaboration.

developed gradually around large sugar factories at Pohronský Ruskov, Šurany, Trnava, and Sládkovičovo.

The Košice Children Historic Railway built in 1956 as a Pioneer Railway, which served to train and motivate young railwaymen, is now one of the tourist narrow-gauge railways. Electric narrow-gauge railways have been built in the
Tatra Mountains and near Trenčín, where the Trenčianska Electric Railway connects the spa town of Trenčianske Teplice with the main railway track. Those railways transport passengers and tourists, and have also a tourist function. Few narrow-gauge railways have been preserved until now (Fig. 8). Particular attention in this article

Table 2. Narrow-gauge railways in Slovakia.

\begin{tabular}{|c|c|c|c|c|c|c|}
\hline Narrow-gauge railways & Original function & $\begin{array}{l}\text { Original } \\
\text { length }\end{array}$ & $\begin{array}{l}\text { Operation } \\
\text { in period }\end{array}$ & $\begin{array}{c}\text { Gauge } \\
(\mathrm{mm})\end{array}$ & $\begin{array}{l}\text { Length } \\
(\mathrm{km})\end{array}$ & $\begin{array}{l}\text { Tourist } \\
\text { function } \\
\text { since }\end{array}$ \\
\hline Čiernohronská railway & forest & 132.0 & 1909-1982 & 760 & 20.0 & 1992 \\
\hline Kysuce - Orava forest railway & forest & 110.0 & 1915-1971 & 760 & 11.3 & 1995 \\
\hline Považská forest railway & forest & 104.0 & 1912-1972 & 760 & 0.1 & 2004 \\
\hline Nitrianska field railway & agricultural & 64.0 & 1895-1971 & 760 & 2.6 & 1985 \\
\hline Forest railway Katarínka & industrial and forest & 70.0 & 1903-1964 & 600 & 0.2 & 2002 \\
\hline Košice children historic railway & tourism & 3.9 & 1956- & 1,000 & 3.9 & 1956 \\
\hline Trenčianska electric railway & $\begin{array}{l}\text { passenger transport } \\
\text { and tourism }\end{array}$ & 5.5 & 1909-2011 & 760 & 5.5 & 2013 \\
\hline Tatra electric railways & $\begin{array}{l}\text { passenger transport } \\
\text { and tourism }\end{array}$ & 35.0 & $1908-$ & 1,000 & 35.0 & 1908 \\
\hline Cog railway & $\begin{array}{l}\text { passenger transport } \\
\text { and tourism }\end{array}$ & 4.8 & $1896-1933$ & 1,000 & 4.8 & 1969 \\
\hline $\begin{array}{l}\text { Starý Smokovec - Hrebienok } \\
\text { funicular }\end{array}$ & tourism & 1.9 & 1908- & 1,000 & 1.9 & 1908 \\
\hline
\end{tabular}

Source: Own elaboration based on data from websites of individual narrow-gauge railways. 
is devoted to the Tatra Electric Railways and the Kysuce-Orava Forest Railway.

The Tatra Electric Railways (TER) are single-track narrow-gauge electric railways and represent a sustainable form of transport in the most attractive mountainous region in Slovakia - the High Tatras. The TER provide connections both for the inhabitants (e.g. commuting to school and work) as well as tourists going to tourist centres and valleys in the High Tatras. The TER have a history more than a hundred years long. The operation on the Poprad - Starý Smokovec railway track started in 1908; on the Starý Smokovec - Tatranská Lomnica section in 1911, and on the Starý Smokovec - Štrbské Pleso section in 1912. The Tatranská Štrba - Štrbské Pleso Cog Railway and the Starý Smokovec - Hrebienok funicular supplement those railways. The Tatranská Štrba - Štrbské Pleso cog railway $(4.8 \mathrm{~km})$ worked in the years 1896 and 1933, and then after 1969. The Starý Smokovec - Hrebienok funicular has been in operation since 1908.

TER trains run with a high frequency (approx. every hour) from early morning to late evening. The timetable is coordinated with other trains on the Košice - Poprad - Žilina track. The TER operator (the Railway Company Slovakia - ZSSK) cooperates with the local government and other subjects in the tourism sector within the High Tatras Regional Tourist Organisation. A close marketing cooperation includes, e.g., joint promotional activities (newsletters, a website, brochures, participation in exhibitions, etc.). The introduction of a regional TATRY card that allows free travel by the TER has contributed to increasing the number of passengers since 2011 (Fig. 9). Other important factors have also been a change in the pricing policy after the closed tariff systems were merged into a single one in 2011, and a rise in domestic tourism in the period of the global economic crisis since 2008. A decrease in the number of passengers in the TER and the Cog Railway before 2009 was mainly a result of growing individual automobile transport and of the windstorm in the High Tatras in 2004 that destroyed a large area of woodland and negatively influenced also the tourism sector.

The advantages of the Tatra Electric Railways are, first, its ecological character, and secondly, the ability to transport a large number of passengers. Ižvolt and Šmalo (2014) discuss possibilities of increasing the territorial coverage and operational performance of the TER in the High Tatras, or connecting the TER track system with the Polish side of the Tatras. It could deconcentrate tourists from overcrowded places on the Polish side, be an alternative to automobile transport, and may have a positive impact on the environment (Więckowski et al. 2012).

The Kysuce-Orava Forest Railway (KOFR) is a narrow-gauge forest railway that served to transport timber in 1915-1971. Two separate

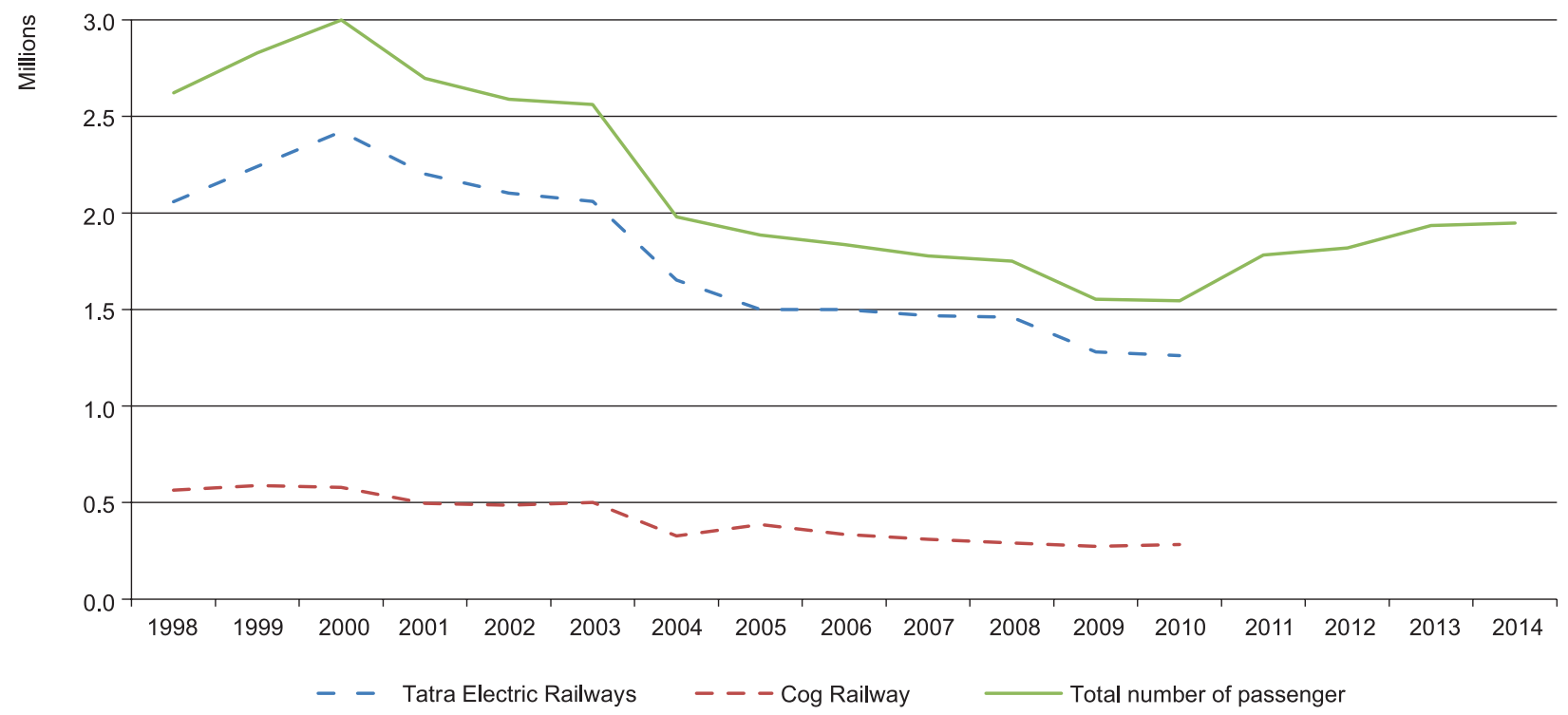

Fig. 9. Number of passengers on the Tatra Electric Railways and on the Tatranská Štrba - Štrbské Pleso Cog Railway.

Source: own elaboration based on data from ZSSK - Railway Company Slovakia. 


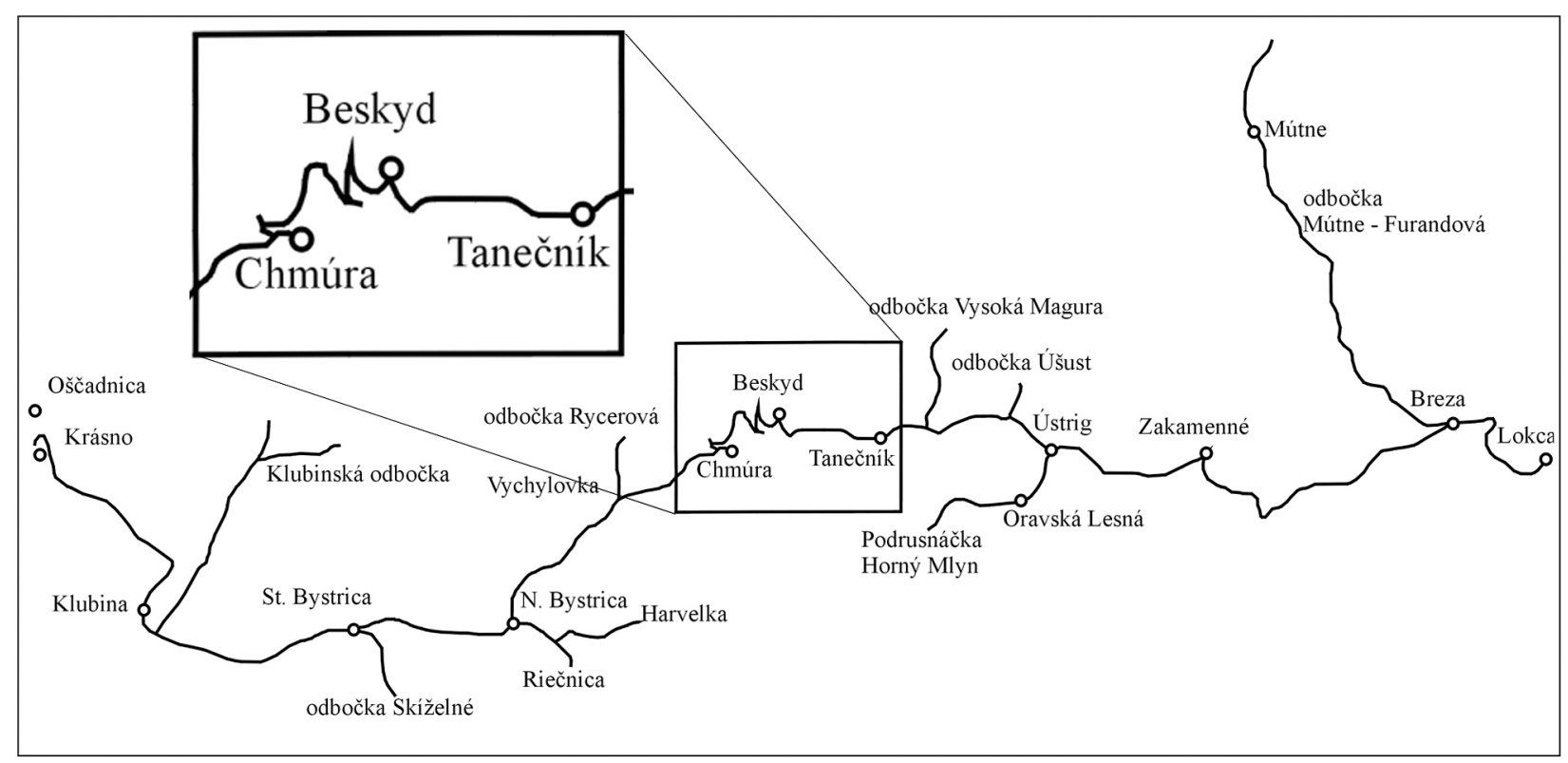

Fig. 10. Tracks of the Kysuce-Orava Forest Railway in 1926.

Source: http:/ /www.kysuckemuzeum.sk/ - adapted by the author.

forest railway systems located in the Kysuce and Orava regions were connected in 1926. In 1971, the railway was disassembled, except for the section from Chmúra to Tanečník (Fig. 10). This preserved section is technically the most interesting part of the former narrow-gauge zig-zag forest railway, and covers a difference in altitude of $217.69 \mathrm{~m}$ at a relatively short distance (the direct distance being 1,500 metres).
The operation of the Historical Logging Switchback Railway in Nová Bystrica Vychylovka (the Kysuce side) started for tourists in 1996. The Orava Forest Railway in Oravská Lesná (the Orava region) came into operation in 2008. There are two operators of the railway, the Kysuce Museum and the Orava Museum, both governed by the Administrative Region of Žilina. The connection of those railways was renovated in 2013 and the trains between the two separated

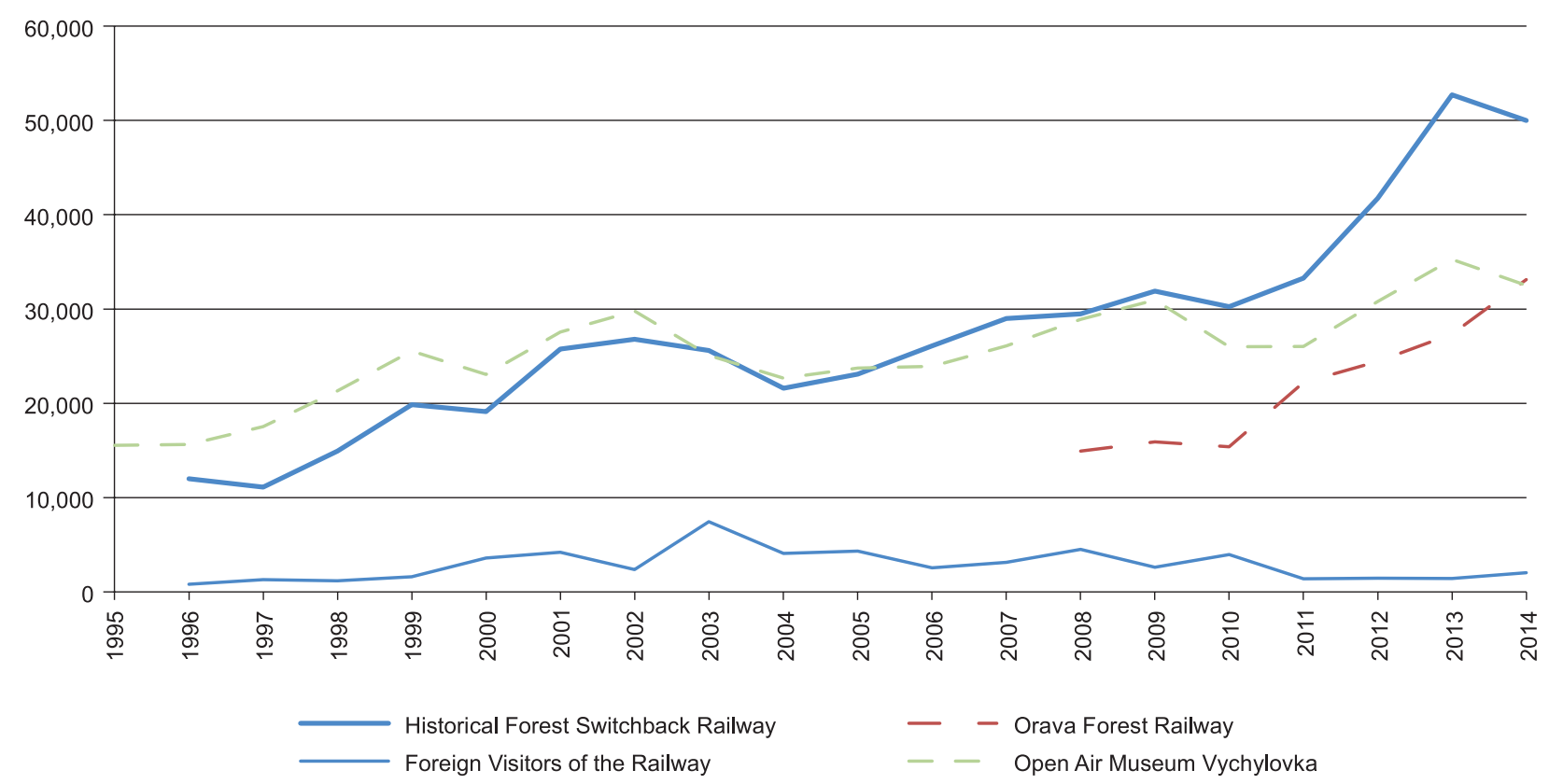

Fig. 11. Number of visitors on the Kysuce-Orava Forest Railway. Source: own elaboration based on data from the Kysuce Museum. 


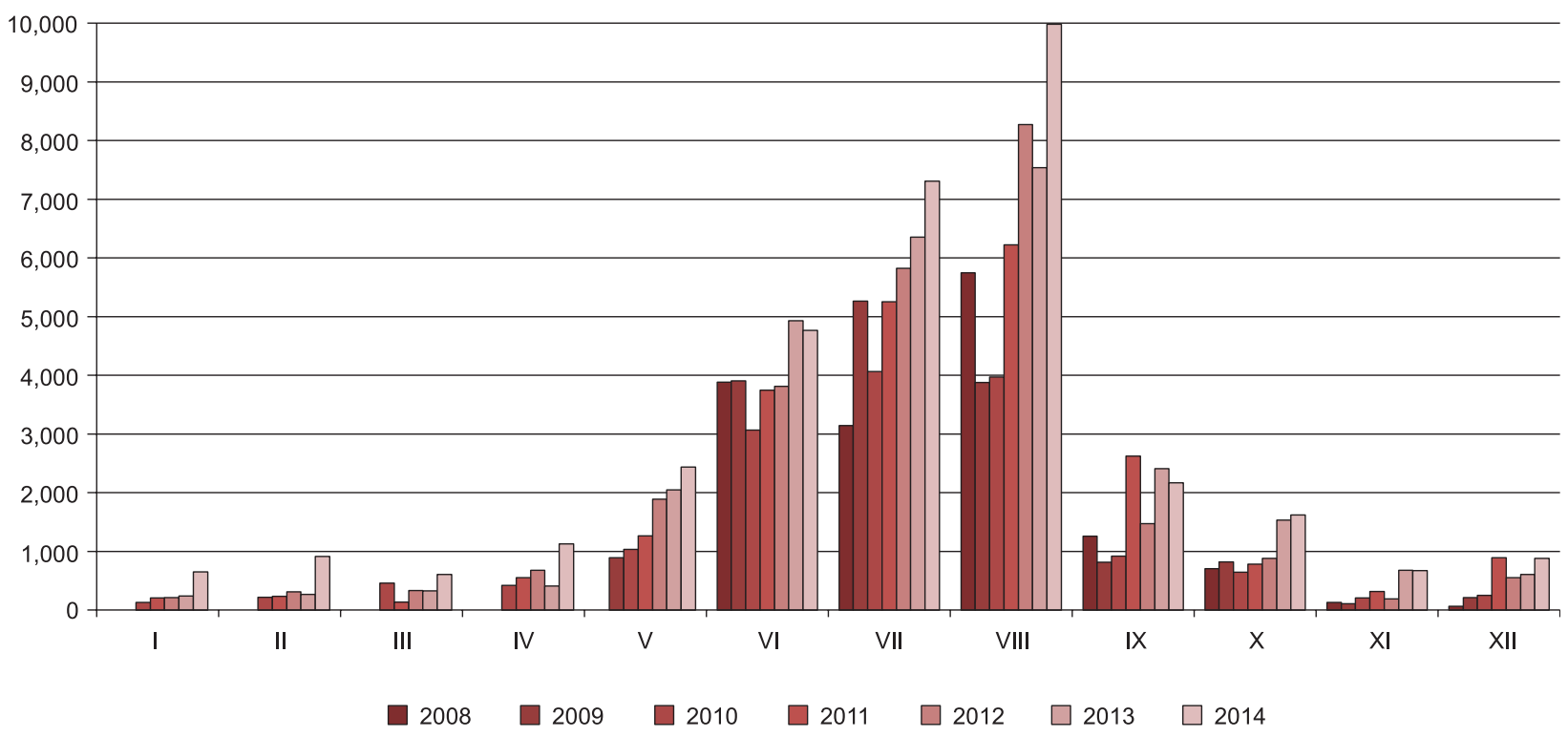

Fig. 12. Seasonal character of tourism on the Orava Forest Railway (the number of tourists). Source: own elaboration based on data from the Kysuce Museum.

parts have been running since the 2015 summer season. While the Kysuce part of the railway operates only from May to October, that of Orava is open all year round.

The railway heritage has the potential to attract a wide spectrum of tourists ranging from children and young people that look for a new experience to an older generation with nostalgic memories of railways in the past. Visitors can visit the Open-Air Museum of Vychylovka as a branch of the Kysuce Museum opened in 1981 because the Kysuce part of the railway goes through the Museum. Fig. 11 presents the number of visitors of the KOFR and the Vychylovka Open-Air Museum. The number of visitors of the railway grew in the monitored period because of the gradual extension of the tourist offer: the railway museum, an old wooden house representing folk architecture, and services such as the new information office. Also interesting is a certain number of foreign tourists. It could be partly a problem of incomplete statistics. A drop in the number of tourists from Poland was observed after the entry of Slovakia into the Eurozone.

A typical feature of tourism in the KOFR is its seasonal character (see Fig. 12). The majority of visitors of the Orava Forest Railway come in summer; the Kysuce part of the railway operates only from May to October.

The KOFR and the TER are examples of socalled (slow) rail tourism, which Blancheton and Marchi (2013) define as tourism or recreation based on slow rail travel for the attractiveness of rail transport itself: the discovery of landscapes, contact with a 'living' heritage, and a search for a new experience.

\section{Conclusions}

The main objective of this paper was to analyse selected problems of railways in Slovakia and present good examples of the use of narrow-gauge railways for the purposes of tourism. A decrease in the importance of railways for passenger transport has been observed in the past 20 years. The evident and gradually widening lagging of railway transport behind individual transport and public bus transport requires decisions concerning the discontinuance of passenger transport on certain lines and the construction (or rather modernisation) of other lines, a cancellation of the existing connections or the establishment of new ones. The closure of passenger transport on many regional railway lines may have a negative impact on the development of tourism, although in some areas, especially more peripheral ones where the demand for rail travel is limited, train services are difficult to turn into a profitable business. Significant modernisation of railway lines takes place only on the main lines in Slovakia, and even there progress is slow. The construction of high-speed railways is not a question of a very near future. 
Railway infrastructure is the only prerequisite for the development of railway transport and for good spatial accessibility of tourist destinations. The organisation of railway transport is important for its efficient operation. From the passenger's point of view, the competition in the passenger railway sector since November 2014 seems to be an important step. In terms of the development of tourism, a positive element may be the introduction of zero-fare public rail transport services, which on the other hand require huge public funds. Such services improve the accessibility of many destinations located near railway tracks. On the other hand, tourist regions and destinations without railway traffic are disadvantaged by this measure. Combining the internal demand (travel to work and school) with the transport demand of the tourism sector is important for the organisation of railway transport.

Narrow-gauge railways represent an important segment in rail tourism in Slovakia. There are some good examples of the use of railways in the tourism sector. The Tatra Electric Railways combine passenger transport of local people with that of tourists in the High Tatras - the most attractive mountain area in Slovakia. A successful way of improving the position of railway transport can be various tourist products (packets) using a combination of rail travel and a visit to various events and tourist attractions. Another good example is the use of the former forest railways like the Kysuce-Orava Forest Railway. It combines the railway heritage (a unique switchback railway) with the cultural heritage (the Vychylovka Open-Air Museum, the Museum of the Kysuce Village). A successful marketing strategy and the development of additional services for tourists lead to a growing number of visitors. The Čiernohronská Forest Railway is another example of a successful operation of narrow-gauge railway for tourist purposes.

In the case of abandoned railway tracks, it is possible to use them for the development of greenways. There are many abandoned tracks in Slovakia that can be used for this purpose (carfree trails) as tourist products (see e.g. Belušák 2013). An example of a greenway is the cycling route in the Slovak-Polish borderland between the towns of Trstená and Nowy Targ, where a continuous, $35-\mathrm{km}$-long cross-border section (14.4 km long on the Slovak side between Trstená and Suchá Hora) uses a former abandoned railway track. Another example is the Ružomberok - Korytnica cycling route ( $23 \mathrm{~km}$ long) that runs mostly along the original route of the former narrow-gauge railway. Mundet and Coenders (2010) point to the importance of greenways as an alternative environmentally friendly communication system, and their growing role in a future low-carbon tourist strategy adapting to climate change.

\section{Acknowledgements}

This article has been prepared under project No. 2/0035/15: Development trajectories of localities and regions - product of sector and spatial policies, territorial capital and decisions, financed by the VEGA Grant Agency.

\section{References}

Belušák L., 2013. Premena opustených železničných tratí na produkty cestovného ruchu - Greenways. Geographia Cassoviensis 7(1): 24-30.

Bílek A., 2000. Lesné železnice na Slovensku. http://rail.sk/ skhist/lz/lz.htm (accessed 30 June 2015).

Blancheton B., Marchi J.-J., 2013. The three systems of rail tourism: French case. Tourism Management Perspectives 5: 31-40.

Boughey J., 2013. From transport's golden ages to an age of tourism: L.T.C. Rolt, waterway revival and railway preservation in Britain, 1944-54. The Journal of Transport History 34(1): 23-38.

Chung J.Y., Whang T., 2011. The impact of low cost carriers on Korean Island tourism. Journal of Transport Geography 19(6): 1335-1340.

Conlin M.V., Bird R.B. (eds), 2014. Railway heritage and tourism: A global perspective. Channel View, Bristol.

Copp C.B, Ivy R.L., 2001. Networking trends of small tourism businesses in post-socialist Slovakia. Journal of Small Business Management 39(4): 345-353.

Čuka P., Némethyová B., Miščíková B., 2012. Short profile of the specific functioning of tourism clusters in Slovakia. Current Issues of Tourism Research 2(1): 32-39.

Dallen J., 2007. The challenges of diverse visitor perceptions: Rail policy and sustainable transport at the resort destination. Journal of Transport Geography 15: 104-115.

Delaplace M., Pagliara F., Perrin J., Mermet S., 2014. Can high speed rail foster the choice of destination for tourism purpose? Procedia - Social and Behavioral Sciences 111: 166-175.

Duval D.T., 2007. Tourism and transport: Modes, networks and flows. Channel View Publications, Clevedon.

EU transport in figures, Statistical Pocketbook 2012, 2012. Publications Office of the European Union, Luxembourg.

Hall D.R., 1999. Conceptualising tourism transport: Inequality and externality issues. Journal of Transport Geography 7: 181-188. 
Halsall D.A., 2001. Railway heritage and the tourist gaze: Stoomtram Hoorn-Medemblik. Journal of Transport Geography 9: 151-160.

Hörz P., Richter M., 2011. Preserved as technical monuments, run as tourist attractions. Narrow-gauge railways in the German Democratic Republic. The Journal of Transport History 32(2): 192-213.

http:/ / www.kysuckemuzeum.sk/ (accessed 30 July 2015).

Ižvolt L., Šmalo M., 2014. Possibilities of increasing territorial coverage and operational performance of the Tatra Electric Railways. Procedia Engineering 91: 441-446.

Jade R., Molková T., Kvizda M., 2015. Role of railways in empowering travelers: A case study from the Czech Republic. Journal of Rail Transport Planning \& Management 5: 31-49.

Johnson M., 1995. Czech and Slovak tourism. Patterns, problems and prospects. Tourism Management 16(1): 21-28.

Kubáček J. (ed.), 1999. Dejiny železníc na území Slovenska. Železnice Slovenskej republiky. Bratislava.

Kumar V., Komaraiah J.B., 2014. Role of Indian railways in promotion of tourism in India: A case study of foreign tourists. IOSR Journal of Humanities and Social Science 19 (1): 22-32.

Lohmann G., Duval D.T., 2011. Critical aspects of the tourism-transport relationship. Woodeaton, Goodfellow Publishers Ltd., Oxford.

Masson S., Petiot R., 2009. Can the highspeed rail reinforce tourism attractiveness? The case of the high speed rail between Perpignan (France) and Barcelona (Spain). Technovation 29: 611-617.

Michniak D., 2006. Accessibility of the railway network in Slovakia. Europa XXI, 15: 51-61.

Michniak D., 2015. Main problems of transport infrastructure development in Slovakia and effects on regional development. Geographia Polonica 88(1): 21-39.

Morháčová J., 2015. Bezplatnú prepravu za rok využilo 24 miliónov l'udí. http://www.slovakrail.sk/ (accessed 18 Nov. 2015).

Mundet L., Coenders G., 2010. Greenways: A sustainable leisure experience concept for both communities and tourists. Journal of Sustainable Tourism 18(5): 657-674.
Page S.J., 2009. Transport and tourism global perspectives. Pearson, Prentice Hall, Harlow, London.

Page S.J., 2014. Tourism management. Routledge, New York.

Prideaux B., 1999. Tracks to tourism: Queensland rail joins the tourist industry. International Journal of Tourism Research 1: 73-86.

Rey B., Myro R.L., Galera A., 2011. Effect of low-cost airlines on tourism in Spain. A dynamic panel data model. Journal of Air Transport Management 1(7): 163-167.

Rodrigue J.-P., Comtois C., Slack B., 2006. The geography of transport systems. Routledge, London and New York.

Stradling S., Anable J., 2008. Individual transport patterns. In: Knowles R.D., Shaw J., Docherty I. (eds), Transport geographies: Mobilities, flows and spaces. Blackwell, Oxford: 179-195.

Tolley, R.S., Turton B.J., 1995. Transport systems, policy and planning: A geographical approach. Longman, Harlow.

Székely V., 2010. Tourism clusters as a tool for the improvement of rural competitiveness: First experiences from Slovakia. In: Fieldsend A. (ed.), Rural areas and development 7: Linking competitiveness with equity and sustainability: New ideas for the socio-economic development of rural areas. IERiGŻ-PIB, Warszawa: 109-120.

Székely V., 2014. From enthusiasm to scepticism: Tourism cluster initiatives and rural development in Slovakia. Studies in Agricultural Economics 116: 74-81.

ŠÚSR, 2015. Database SLOVSTAT. Statistical Office of the Slovak Republic. http://slovak.statistics.sk/ (accessed 30 July 2015).

Vystoupil J., Kasagranda A., Šauer M., 2016. Funkčně-prostorová typologie středisek cestovního ruchu Ceska a Slovenska. Geografický časopis 68(2): 171-192.

Więckowski M., Michniak D., Chrenka B., Ira V., Komornicki T., Rosik P., Székely V., Śleszyński P., Wiśniewski R., 2012. Možnosti zlepšenia dostupnosti a rozvoja cestovného ruchu v pol'sko-slovenskom pohraničí - námety, odporúčania a dobré príklady. IGiPZ PAN, Varšava; Geografický ústav Slovenskej akadémie vied, Bratislava.

Williams A.M., Baláž V., 2002. The Czech and Slovak Republics: Conceptual issues in the economic analysis of tourism in transition. Tourism Management 23: 37-45. 